\title{
An evaluation of the macro-scale adoption of Building Information Modeling in Chile: 2013-2016
}

\author{
Evaluación de la adopción a macro-escala de Building Information Modeling en Chile: 2013-2016
}

Mauricio Loyola (Main and Corresponding Author)

Departamento de Arquitectura, Universidad de Chile

Av. Portugal 84, Santiago (Chile)

mloyola@uchile.cl

\section{Felipe López}

Departamento de Arquitectura, Universidad de Chile

Av. Portugal 84, Santiago (Chile)

felipelopezta@ug.uchile.cl

Manuscript Code: 994

Date of Acceptance/Reception: 02.04.2018/30.10.2017

DOI: $10.7764 /$ RDLC.17.1.158

\begin{abstract}
In recent years, there has been growing public and private interest in Chile in implementing plans promoting the use of Building Information Modeling. However, the lack of local studies hinders the creation of policies suited to the particular conditions of the country. In response, we present a comprehensive analysis of the evolution of the macro-scale adoption of BIM in Chile during the 2013-2016 period, based on two national surveys conducted among architecture, engineering and construction (AEC) professionals. At first glance, the overall results coincide with other countries with similar development level, but a more detailed analysis evidences unique local conditions. There are dramatic differences in BIM expertise among AEC disciplines, which in turn leads to heterogeneous, fragmented, and non-collaborative BIM practices. Although BIM users account for more than half of respondents, they are mainly occasional users that only take advantage of the most basic capabilities of the technology. The study also shows strengths and potential opportunities for improvement. In the end, this study reveals the unique conditions of the technology adoption process in Chile, and consequently, contributes to identifying specific strengths, problems, and areas of action that should be addressed by any public or private BIM promotion plans.
\end{abstract}

Key words: Building Information Modeling, technology diffusion, Chilean AECO industry.

\section{Resumen}

En los últimos años, ha surgido un creciente interés público y privado en Chile en la implementación de planes que promuevan el uso de Building Information Modeling. Sin embargo, la falta de estudios locales dificulta la creación de políticas adecuadas a las condiciones particulares del país. En respuesta a este problema, presentamos un análisis exhaustivo de la evolución de la adopción a macro-escala de BIM en Chile durante el período 2013-2016, realizado sobre la base de dos encuestas nacionales aplicadas a profesionales de arquitectura, ingeniería y construcción (AEC). A primera vista, los resultados globales coinciden con otros países con un nivel de desarrollo similar; pero un análisis más detallado evidencia condiciones locales distintivas. Existen diferencias dramáticas en el conocimiento sobre BIM entre las distintas disciplinas AEC, lo que a su vez conduce a prácticas BIM heterogéneas, fragmentadas y no colaborativas. Aunque los usuarios de BIM representan más de la mitad de los encuestados, se trata principalmente usuarios ocasionales que solo aprovechan las capacidades más básicas de la tecnología. El estudio también muestra fortalezas y posibles oportunidades de mejora. Al final, este estudio revela las condiciones únicas del proceso de adopción de tecnología en Chile y, en consecuencia, contribuye a identificar fortalezas, problemas y áreas de acción específicos que deben ser abordados por cualquier plan de promoción BIM público o privado.

Palabras clave: Building Information Modeling, Difusión de tecnología, Industria de la construcción

Introduction

\section{Description of the Problem}

Several academics and practitioners have claimed that the highest benefits of the use of Building Information Modeling (BIM) are achieved when all participants in the Architecture, Construction, Engineering, and Operation (AECO) industry work collaboratively. In fact, the multidisciplinary use of the technology not only brings private benefits to its direct users and their projects, but also has positive externalities across the whole industry. The widespread adoption of BIM, they have argued, contributes to improving overall levels of productivity, competitiveness, sustainability, and safety in the AECO sector (Eastman, Teicholz, Sacks \& Liston, 2011; Azhar, 2011; Gu, Singh \& London, 2014; Barlish \& Sullivan, 2012; Bryde, Broquetas \& Vasquez, 2013; Bonilla \& Garcia, 2017). 
For this reason, several public and private organizations in North America and Europe have conducted studies, implemented plans, and developed guidelines aimed to promoting the adoption of BIM in their industrial contexts (AGC, 2007; BCA, 2012; buildingSMART, 2017; CRC, 2009; GSA, 2009; Statsbygg, 2017; Wong, Wong \& Nadeem 2009). Other organizations in Asia and Latin America have begun to follow their example, inspired by the good results obtained (ASOBIM, 2017; BFA, 2017; BFCh, 2017; BFM, 2017; Kassem \& de Amorim, 2015). Unfortunately, the characteristics of the $A E C O$ industries in other regions can be radically different, making the recommendations of leading countries not easily transferable nor applicable.

An example is Chile, where in recent years the government and the private sector have joint efforts in developing plans for the promotion of BIM technology in the country (Soto, 2016; Nala, 2016; PlanBIM, 2017), having only international references as guides. The adoption of BIM in Chile could be traced back until the 1990s, but it was around mid-2000s when a sustained diffusion process began. For almost a decade, the adoption of technology grew in the country as isolated initiatives by AEC firms and architecture schools, without any systematic coordination at the country level.

In response to this urgent need for local studies, this paper contributes by providing updated, complete, and representative information on the use of BIM in Chile. Specifically, we characterize and evaluate the evolution of the adoption of BIM in a macro-scale in the period 2013-2016, based on the comparative analysis of two national surveys conducted those years.

The ultimate goals of this study are, first, to gain useful insights about the Chilean situation that may be used to facilitate decision-making among local private and public stakeholders, and second, to contribute to the mapping of BIM adoption around the world.

Background

\section{State of the Art}

Abundant research on macro-scale BIM adoption studies has been carried out by governmental, professional, commercial, and academic institutions. Most studies have been conducted in countries in North America, Europe, and East Asia that have competitive software and construction industries and markets.

Unfortunately, these studies are methodologically very dissimilar, so it is impossible to make direct comparisons of their results.

In general, the studies are based on in-depth case studies or, more frequently, self-administered online surveys distributed among AECO professionals, with sample sizes ranging from $\sim 50$ to $\sim 1,500$ respondents. Although contents vary significantly, most of these surveys share questions about adoption levels, uses, implementation costs, business benefits, collaboration practices, interoperability, and standards.

Studies carried out by governments and professional associations tend to have large sample sizes and focus on metrics of adoption, collaboration, interoperability, and standards. For example, the studies conducted in Finland (Henttinen, 2010; RTS, 2013), India (Sawhney et al., 2014), Korea (Won, Lee \& Park, 2010), Middle East (Sharif, 2011), and United Kingdom (NBS, 2017).

Commercial studies tend to focus on implementation costs, business value, economic benefits, and software market share. Probably the most respected studies in this group are those conducted by McGraw-Hill Construction in different global markets: United States (McGraw-Hill 2009, 2012a); United Kingdom, France and Germany (McGraw-Hill, 2010); Korea (McGraw-Hill, 2012b); Canada (McGraw-Hill, 2012a); Australia and New Zealand (McGraw-Hill, 2014a); China (McGraw-Hill, 2014b); and Brazil and Japan (McGraw-Hill, 2014b).

Academic studies tend to have more methodologically rigorous and focused objectives, but their results are less applicable and transferable to practice. There are academic studies in a considerable amount of countries: China (Xu, Feng \& Li, 2014; Cao et al., 2015; Zhang, Wang, Chen \& He, 2014; Ding, Zuo, Wu \& Wang, 2015); Denmark (Anker Jensen \& Jóhannesson, 2013; Movsisyan, 2016), Iceland (Kjartansdóttir, 2012), India (Luthra, 2010; Kumar \& Mukherjee, 2009), Malaysia (Enegbuma \& Ali, 2011; Teo, 2012; Latiffi, Mohd, Kasim \& Fathi, 2013; Mohd-Nor \& Grant, 2014), Portugal (Carvalho, 2016; Silva, Salvado, Couto \& Azevedo, 2016), South Africa (Kekana, Aigbavboa \& Thwala, 2014; Froise \& Shakantu, 2014), Spain (Silvia, del Solar, de la Peña \& Vivas 2017), Sweden (Hooper, 2015), United Kingdom (Eadie, Browne, Odeyinka, McKeown \& McNiff, 2015; Khosrowshahi \& Arayici, 2012), United States (Sattineni \& Bradford, 
2011), and various cross-country comparisons (Bui, Merschbrock \& Munkvold, 2016; Gu, Singh, Tylor, London \& Brankovic, 2010; Jung \& Lee, 2015; Kassem, Succar \& Dawood, 2013; Smith, 2014; Wong et al., 2009; Wong, Wong \& Nadeem, 2010).

Among the few studies carried out in Latin America, other than in Chile, are in Brazil (Checcucci, Pereira \& Leusin de Amorim, 2011; de Andrade \& Ruschel, 2009; Kassem \& de Amorim, 2015; Ferreira, 2012), Mexico (FIC, 2017), Colombia (Botero et al., 2015), and cross-crountry comparisons (Leon, 2017).

Probably the best background study to use as frame of reference/benchmark in this case is the first Latin-American BIM Survey conducted in 2017 by the Inter-American Network of Innovation Centers in Construction (INCONET, for its acronym in Spanish), subsidiary of the Inter-American Federation of Construction Industry. This survey was conducted on 17 countries and was designed based on the two Chilean BIM surveys which are reported in this paper, so part of the methodology and questionnaire is very similar (Leon, 2017), and therefore, offers a better comparison reference than other valuable but dissimilar studies. The INCONET study shows that Chile, Mexico, Colombia, Costa Rica, and Brazil are the clear leaders in BIM adoption in the region. Chile has the largest proportion of users and also the largest percentage of BIM projects carried out by users, closely followed by Costa Rica and Colombia. In general, the most frequent uses of BIM in the region are related to the early phases of the project development process: visualization during design, production of 2D drawing, and coordination of structure/MEP systems. The full report can be found in Leon (2017).

\section{Context of BIM in Chile}

Although the use of BIM in Chile can be traced back to the end of the 1990s when some universities, began teaching and researching with Microstation and ArchiCAD (PUC, UCH and USACH architecture schools), it was not until the mid2000s that a process of sustained growth and diffusion was consolidated (Montoya, 2008; Chiappa, 2010; Ruiz, 2012; Pavez, 2012; Lobos, 2016a, 2016b). In 2004, BIM was adopted by only a few AEC firms (e.g. Montealegre Beach Arquitectos, Cruz y Dávila Ingeniería, etc.), and some government agencies (e.g. MOP) and professional associations (e.g. CDT) were exploring, very incipiently, the value of the technology. However, in just a few years, the spread of BIM grew exponentially. Towards the end of the 2000s, there were dozens of AEC companies using BIM consistently in their projects; the first BIM consulting firms had been founded; and the government had declared its interest in testing the technology. However, all these were isolated initiatives without transversal coordination in the industry until 2011, when the first efforts for industry-wide coordination were led by professional associations (CDT) and academia (PUC, UCH) (Lobos, 2016b). The government-led BIM initiative (PlanBIM) was initiated in 2015.

In 2013, the start date of this study, BIM technology had substantial presence in the industry. There were, at least, 6 distributors and/or resellers of BIM software products, predominantly Autodesk Revit, Graphisoft ArchiCAD and Tekla Structures. Leading professional organizations had organized more than a dozen seminars and extension activities (CDT, 2010). Some universities had offered continuing education courses and appointed new professors trained overseas to conduct research in the area. The Government of Chile had piloted the BIM technology in a few public projects and was examining the technical and legal procedures to require the use of BIM formally in future projects (Lobos, 2013).

In 2016, the end date of this study, the diffusion and penetration of BIM in the industry was patently evident (Saavedra, 2016). All professional organizations had established special committees or working groups to study and promote the use of BIM in their respective domains, including BIM Forum Chile, a consortium of AECO companies created with the explicit aim of promoting the technology in the country (BFCh, 2017). The number of pilot public projects designed and built with BIM systems had increased exponentially. In fact, the Chilean government had officially declared its intention to mandate BIM in all public projects by 2020 (Plan BIM, 2017). In academia, most universities were offering BIM courses at the undergraduate or graduate levels, and at least two international BIM conferences had been held in the country (BIM Latam, 2015, 2016).

Methods

The longitudinal analysis presented in this paper is based on two national surveys conducted in October 2013 and April 2016. Both surveys were carried out by the authors and were nearly identical in their methodology.

In both surveys, a self-administered, adaptive web questionnaire was used. Private invitations were sent by e-mail to all professionals registered in any of the 10 leading professional organizations of the Chilean AEC industry, namely the Chilean Association of Architects, the Chilean Association of Civil Engineers, the Chilean Association of Construction 
Engineers, the Association of Architecture Firms, the Association of Structural Engineers, the Chilean Chamber of Construction, the Corporation of Technology Development, and BIM Forum Chile.

The use of a self-administered instrument and a self-selected sample carries a natural bias towards those who are interested in the subject of the survey. In BIM studies, this bias translates into an overestimation of technology adoption and maturity levels. In this case, to partially counteract this undesired effect, the survey invitation message and the survey introduction made explicit reference to the fact that the survey was aimed at "all" AECO professionals (and not just BIM users). Also, several collaborating professional organizations encourage participation in the survey through independent e-mail messages or notes in their newsletters. Post-hoc statistical corrections (as Heckman's lambda) are not possible because the distribution is unknown and hard assumptions (e.g. normality) can be misleading.

The sample size was 810 responses in the 2013 survey and 1,338 responses in the 2016 survey, about 5\% response rate. The instrument used was an adaptive 30-item questionnaire with 15 multiple-choice questions and 15 Likert scale questions. Originally, the 2013 instrument had 36 items, but 6 questions were eventually discarded because of low response rate. A first draft of the questionnaire was prepared by the research team based on similar surveys found in the literature, circulated among distinguished national BIM scholars asking for comments, and finally piloted in a closed 30-people group. The final refined questionnaire is available to the academic community on the research project website www.bim.uchilefau.cl

The survey website was hosted on academic servers, free from any reference to any company or institution related to BIM. The data were treated with total confidentiality in accordance with institutional research ethics policies.

Results were analyzed with the statistical environment R. Central tendency and dispersion statistics were calculated for all variables using confidence intervals for each sub-sample with $95 \%$ confidence and maximum variability. In general, the margin of error ranges between $\sim 4 \%$ for questions involving all respondents and $\sim 9 \%$ for sub-sample questions.

To facilitate comparisons between sub-samples in some 5-level Likert-scale questions, we defined the normalized metric $\beta$ as the log of the ratio of the number of responses in the two positive/highest categories (e.g. "always + frequently") over the number of responses in the two lowest categories (e.g. "occasionally + never"). A negative $\beta$ indicates predominance of the negative/lowest categories, a positive $\beta$ indicates predominance of the positive/highest categories and a value close to 0 indicates neutrality.

Pearson's Chi-Square $\left(\chi^{2}\right)$ tests for categorical data were used to evaluate independence between variables and goodness-of-fit in inter-annual comparisons. Spearman's Rho $(\rho)$ Correlation Coefficient for Ordinal Data and Kendall's Tau $(\tau)$ Association Coefficient were calculated to evaluate associations between variables, where relevant. For multicomparisons among several groups and surveys, we use the Kruskal-Wallis H Test, as a rank-based substitute for ANOVA categorical data in Likert-scale questions. Significance results for all these tests are reported as $p$-values, with $\alpha=0.01$.

After each survey in 2013 and 2016, a simplified summary of the main results was released targeting the general public (Loyola, 2013; Loyola, 2016a; Loyola, 2016b). This paper, instead, presents a longitudinal analysis comparing both surveys, with deeper and more statistically rigorous analysis intended for the scientific community.

The following section gives a detailed report of the results of the survey. Where appropriate, additional comments about the Chilean AECO industry have been provided as context for interpreting the results.

Results

\section{Levels of use}

Based on frequency of use, the study classified respondents into four groups: 1) regular users, i.e. those who had used BIM with several or most of their projects in the last 12 months; 2) occasional users, i.e. those who had used BIM with only a couple of their projects in the last 12 months; 3 ) indirect users, i.e. those who had used BIM only through external outsourced BIM consulting services; and 4) non-users, i.e. those who had not used BIM at any level in the last 12 months.

Overall, a statistically significant $p<0.001$ growth of total users was observed, from $40.4 \%$ in 2013 to $53.5 \%$ in 2016 . The proportion of occasional users and external users doubled in this period $(13.9 \%$ to $27.4 \%$ and $2.3 \%$ to $3.9 \%$, respectively), while the number of regular users remained stable (Figure 1). 
There are indisputable differences between disciplines, a situation that, in fact, was consistently observed in answers to several questions in the study. Architects have the highest levels of use and the largest proportion of users (62.9\% total users and $28.5 \%$ regular users in 2016). In contrast, mechanical, electrical, and plumbing engineers (MEP) have the smallest proportion of users (39.1\% total, $12.1 \%$ regular in 2016) (Figure 2). Remarkably, among contractors, a significant growth $(p<0.01$ ) of occasional users $(9.4 \%$ to $22.3 \%)$ and external users $(3.9 \%$ to $6.4 \%)$ was observed, yet there was a corresponding decline of regular users ( $16.5 \%$ to $10.4 \%)$.

Despite the common assertion that, in Chile, the use of BIM is concentrated almost exclusively in AECO companies based in the country's capital Santiago, this study revealed no significant differences between the metropolitan region and any other region of the country, even after normalizing by population, building permits, and construction costs.
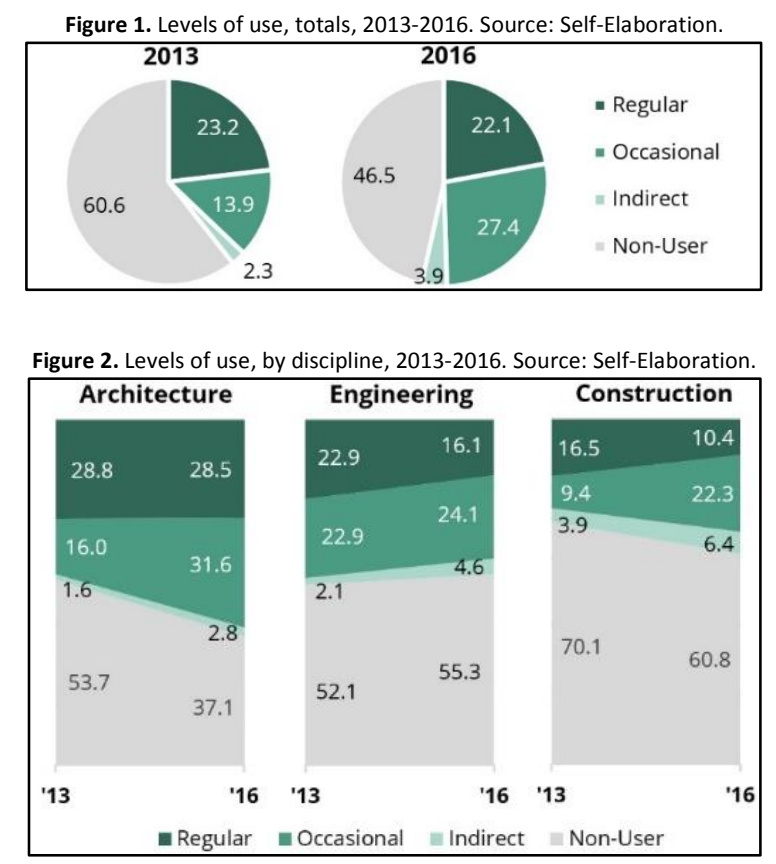

\section{Software tools}

Autodesk Revit is the dominant software tool in the Chilean market, used by almost three quarters of all professionals (76.7\%), followed by ArchiCAD, which is used almost exclusively by architects (Figure 3). Revit is the most used tool in all groups (levels of use, discipline), and in fact, $47.1 \%$ of all professional use only this tool.

The absolute preeminence of Revit, coupled with the absence of other relevant software providers (Bentley, Nemeteshek, Solibri, etc.), and the lack of open standards, is an indicator of a potentially detrimental software monopoly situation. However, Chile experiences high rates of software piracy, so it is uncertain if these numbers are truly representative and, accordingly, could be used to infer market metrics (e.g. revenue market share).

The distribution of BIM tools usage is similar in both surveys, with the only exception being Autodesk Navisworks which dropped significantly over the study period, from $39.4 \%$ in 2013 to $28.9 \%$ in 2016 among regular users. Considering that this BIM software tool is typically used for assisting construction project reviews, these numbers could be an early signal of a stagnation in advanced uses of BIM in construction phases.

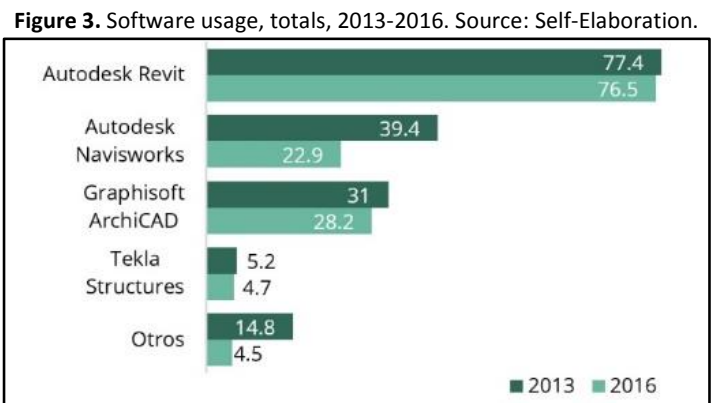




\section{Project types}

Both the 2013 and 2016 surveys showed a similar transverse use of BIM in all types of projects and buildings (i.e. industrial, healthcare, retail, office, residential, educational, etc.). At the beginning of BIM in Chile, technology was used almost exclusively in industrial and health buildings. The study showed that this is no longer the case. There were no discernible trends beyond those that can be simply explained by the normal fluctuation of the construction market.

Perhaps the only noteworthy variation in the period was the statistically significant $(p<0.01)$ growth of BIM usage in small projects (less than $250 \mathrm{~m}^{2}$ ), from $41.2 \%$ to $50.9 \%$. A deeper analysis shows that the increase can be explained mostly ( $52 \%$ of the variation) by a burst in use among occasional users. A reasonable interpretation could be that these small projects led by occasional users are, in reality, pilot projects among novel users who are prudently exploring the applications of the technology.

\section{BIM capabilities}

Figure 4 shows the reported of use of some of the most commonly used BIM capabilities.

The most frequent uses $(\beta \geq 0.5)$ include visualization during the design process and the production of construction documents. Some less frequent, but still widely used capabilities $(0<\beta<0.5)$ involve detailing, structural and MEP systems coordination, photorealistic renderings and material take-offs. The less frequent uses $(\beta \leq 0)$ include cost estimating, construction scheduling, construction management, project review and facility management.

Comparing regular users between 2013 and 2016, the use of BIM for visualization and production of construction documents increased in frequency, while capabilities related to construction phases (cost estimating, construction scheduling, construction management, project review) decreased in frequency (average decrease rate $=0.14, p<$ $0.01)$.

The low frequency of use of construction-related BIM capabilities was an unexpected result. In Chile, construction and project management companies were pioneers in the implementation of BIM technologies (Chapple, 2009) and, therefore, these capabilities could reasonably be expected to have a higher level of use. Instead, the study showed that builders and contractors used BIM virtually only to coordinate MEP systems and obtain material quantity take-offs. This is very inefficient since once a BIM model has been created with a level of detail sufficient to extract material quantities, the amount of additional work required to use it in construction management is substantially marginal compared to the benefits that can be obtained.

Among indirect users, the most frequently used BIM capabilities were, by far, the production of clash reports and systems coordination drawings for constructability reviews (41.8\% and $40.4 \%$ respectively, average 2013-2016). However, there is no Chilean standard for BIM documentation, so the scope of these documents and reports may vary significantly. Some firms may deliver simply automated reports as they are generated by the software tool, while others may be producing custom in-depth conflict analysis reports.

Surprisingly, very few indirect users request native BIM files from consultants: $23.1 \%$ in $2013,16.7 \%$ in 2016 , a decreasing trend $(p<0.01)$. As matter of fact, the poor collaboration and low levels of sharing of BIM files is a generalized phenomenon in the Chilean industry, even among regular users. Drawings in CAD files remain as predominant means of communication among AECO professionals: more than three-quarters (77.7\%) of BIM users utilize 2D CAD to communicate and collaborate with peers, even among professionals who also use BIM.

It should be noted that in Chile the submission of digital information for building permits is not allowed (OGUC, 2016), so, strictly speaking, traditional drawings on paper are the only official method for technical documentation.

\section{Benefits}

In both 2013 and 2016, the most frequently perceived benefits of BIM use were the reduction of errors in construction documents $(\bar{\beta}=+1.49)$, decreased project development time $(\bar{\beta}=+1.26)$, and improvement in the quality of the project $(\bar{\beta}=+1.24)$. There was an increase in $2013-2016$ in the number of professionals who reported reduced construction time $(+38.7 \%$ over $\beta)$ and cost savings $(+24.6 \%)$. 
Figure 4. BIM capabilities, total users, 2016. Source: Self-Elaboration.

\begin{tabular}{|c|c|c|c|c|c|c|}
\hline Visualization during design process & & & $3.6-16.9$ & 26.0 & 46.8 & $\beta=0.55$ \\
\hline Production of construction documents & & & $\begin{array}{ll}8.8 & -14.3 \\
\end{array}$ & 24.4 & 42.8 & $\beta=0.46$ \\
\hline Detailing & & -19.6 & -19.2 & 18.8 & 31.0 & $\beta=0.11$ \\
\hline Structural design coordination & & -17.0 & -23.8 & 18.9 & 30.7 & $\beta=0.08$ \\
\hline Photorealistic renderings & & -25.4 & -18.0 & 18.2 & 29.6 & $\beta=0.04$ \\
\hline Electrical/Plumbing systems coordination & & -30.8 & -17.0 & 16.7 & 26.2 & $\beta=-0.05$ \\
\hline Quantiy Takeoff & & -35.3 & -18.1 & 16.1 & 21.3 & $\beta=-0.16$ \\
\hline Mechanical systems coordination & & -30.7 & -18.2 & 19.8 & 18.9 & $\beta=-0.11$ \\
\hline Construction Management & -56. & & -17.2 & $8.4 \quad 7.4$ & & $\beta=-0.67$ \\
\hline Scheduling & -57 & & -17.6 & $\begin{array}{ll}6.7 & 10.2 \\
\end{array}$ & & $\beta=-0.65$ \\
\hline Facility Management & -68 & & -12.8 & $\begin{array}{lll}5.8 & 7.3\end{array}$ & & $\beta=-0.80$ \\
\hline$=$ Never & \# Ocasionally & Half & times & equently & - Always & \\
\hline
\end{tabular}

A positive association was observed between frequency of use and level of benefits ( $\tau=0.52, p<0.001)$, meaning that the more frequent BIM was used, the greater the level of benefits that were obtained.

Notably, post-hoc tests showed no statistically significant differences between the level of benefits perceived by occasional and indirect users. Regular users, in contrast, reported a significantly higher $(p<0.001)$ level of benefits. A similar phenomenon was observed with the level of satisfaction. This may suggest that shifting from indirect to occasional use does not generate a significant increase in the level of benefits or satisfaction, but upgrading from occasional regular use, on the other hand, does.

Another consistent -although inauspicious - result found in both surveys, was that building occupants are recognized as the least benefited group by BIM technology. Architects and builders were perceived as the most benefited groups. This situation is not at all desirable. If BIM is perceived to be a technology that grants benefits exclusively to project professionals, but not to the end users of buildings, then it will become more difficult for the technology to be valued (and consequently, required) by owners and clients.

\section{Level of satisfaction}

In general, the level of satisfaction with BIM use, measured on a scale from 1 to 10, was 8.40 in 2013 and 7.35 in 2016, representing a statistically significant $(p<0.01)$ decrease of $12.5 \%$. This variation may seem alarming at first, but a deeper analysis allows us to weigh its causes.

In 2013, all users reported similar levels of satisfaction, with no significant differences between disciplines or levels of use. In 2016, however, important differences were observed between users. Regular users had a satisfaction level of 8.36, significantly higher $(p<0.001)$ than occasional users (6.37) and indirect users (6.17). Post-hoc tests showed that between disciplines significant differences were also existent, with the distance between architects and MEP professionals being the most extensive and statistically significant $(p<0.01)$. Although all sub-samples showed decreases in satisfaction levels, engineers $(-18.1 \%)$, and particularly structural engineers $(-19.4 \%)$, had the sharpest drops. Only regular and indirect users had no statistically significant variation.

Although it is possible to offer different explanations for this variation, the positive association found between frequency of use and level of satisfaction $(\tau=0.38, p<0.001)$ provides an important clue: the more frequent the use, the greater the level of satisfaction with the technology. Architects have the highest level of use, followed by builders, structural engineers and MEP specialists. Satisfaction levels demonstrate the same pattern. BIM consultants have an average satisfaction level of 8.66 .

\section{Factors influencing adoption}

The most important factor influencing the diffusion of BIM, according to the respondents, is the extent to which "other companies/professionals" use the technology $(\bar{\beta}=+0.85)$. A possible explanation for this is that, in Chile, few dare to invest in BIM without having the support that it is a cross-industry trend. As a matter of fact, compared to more developed countries, investment in research and development in the Chilean AECO sector is significantly lower (Serpell et al. 2002). 
Figure 5. Satisfaction levels, 2013-2016. Source: Self-Elaboration.

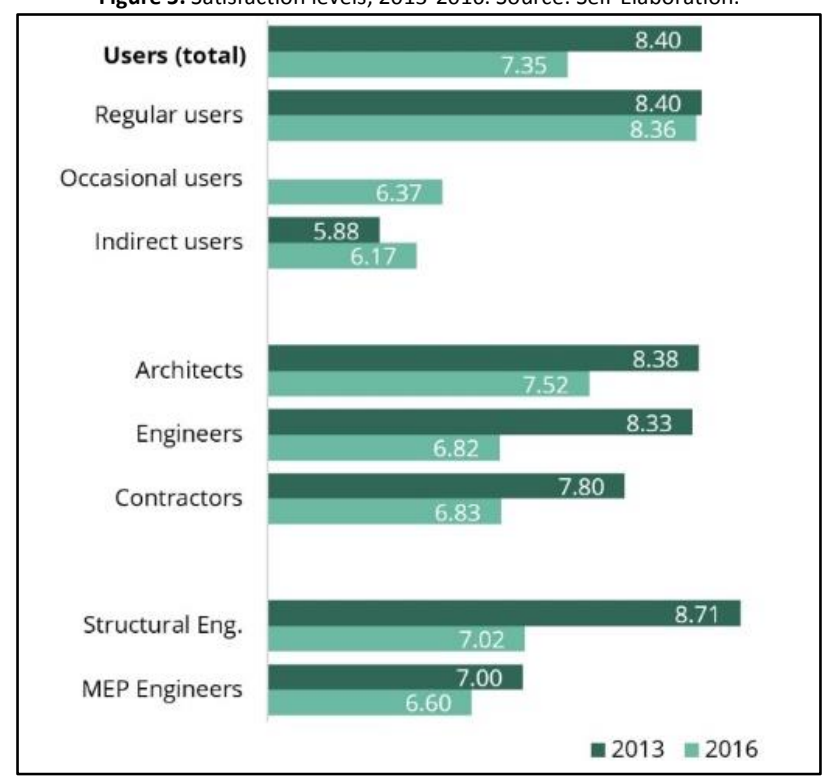

Another factor declared as influential is the [greater] availability of trained young professionals $(\bar{\beta}=+0.82)$. This factor showed an increase rate between 2013 and 2016 of 10.2\%.

The role of the government and public sector appears to be substantially less influential $(\bar{\beta}=+0.47)$, a result which is consistent with other survey questions: in 2016, 65.4\% of users indicated that their main motivation for BIM implementation was their own initiative, whereas only $24.0 \%$ stated that it was required by a public entity for a public project. It remains to be seen how the new government program Plan BIM 2020 (Soto, 2016) will affect this result in coming years.

\section{Non-Users}

Although the number of non-users diminished in the study period (59.6\% to $46.5 \%$ ), the level of (un)knowledge about BIM among them remained stable. Approximately one-third (31.2\% in 2013 and $30.8 \%$ in 2016) of non-users claimed to have no knowledge of the technology ("never heard of BIM"). The number of non-users declaring having a "general understanding" of the technology, increased slightly from $21.5 \%$ in 2013 to $25.5 \%$ in 2016.

More dramatic differences were revealed after disaggregating results by discipline: More than one-half of non-users engineers (57.0\% in 2016) reported having never heard of BIM. Among MEP engineers, this number increased to $66.1 \%$. In contrast, architects appeared to be the most informed group: $57.7 \%$ of non-users knew the technology and $16.7 \%$ had also basic training on at least one BIM software tool.

Table 1. Knowledge about BIM, Non-Users, 2013-2016. Source: Authors.

\begin{tabular}{lllll}
\hline & Table 1. Knowledge about BIM, Non-Users, 2013-2016. Source: Authors. & & \\
& 2013 & 2016 & $\bar{x}$ & var \\
\hline Know how to use BIM & $10.4 \%$ & $10.3 \%$ & $10.4 \%$ & -0.005 \\
Have detailed understanding & $36.9 \%$ & $33.3 \%$ & $35.1 \%$ & -0.097 \\
Have general understanding & $21.5 \%$ & $25.5 \%$ & $23.5 \%$ & 0.186 \\
Never heard of BIM & $31.2 \%$ & $30.8 \%$ & $31.0 \%$ & -0.010 \\
\hline
\end{tabular}

\section{Adoption rate surpassed a critical point}

The results show that the use of BIM in Chile has reached a critical mass which suggests that the mass adoption of the technology is a trend that will likely continue over the next few years. All metrics in this study seem to confirm this tendency. 
First, as basic indicators, the current number of users surpasses the number of non-users, and the observed growth rate is an auspicious $32.6 \%$ for the 3-year period. There are no signs that a plateau will be reached in the short term as the growth rate is mainly due to an increase of occasional users; there is ample room for them to become regular users, and for non-users to become users.

The levels of satisfaction with the technology are high or very high for all groups evaluated. The perceived future use also shows positive numbers: about $93.6 \%$ of them believe that their use of BIM within the next 12 months will be equal, greater, or much greater than today (2016). Moreover, there is a strong positive association between the frequency of use and the level of satisfaction $(\tau=0.38, p<0.001)$ : the more frequent the use of BIM, the greater the satisfaction with the technology.

But there are not only positive evaluations from users. At the same time, there seems to be very little aversion to technology from non-users, a key factor for predicting its diffusion. Among non-users, more than $73.2 \%$ are interested and willing to implement or evaluate the implementation of the technology within the next 12 months (2016).

At a global scale, the results corresponded with those observed in other user countries with similar technology development levels. The adoption rate is similar to what was found in United States or northern Europe about 10 years ago (Eastman, 2016). In general, these surveys show that the BIM adoption and maturity levels in Chile are slightly higher than other Latin-American countries, closely followed by Mexico, Colombia, Brazil and Costa Rica (Leon, 2017). Remarkably, the proportion between regular, occasional, and non-users and the relative frequency of use of typical BIM capabilities is similar to other leading Latin-American countries, which may be an indication of common technology diffusion process patterns in the region.

\section{Strong differences between disciplines}

One of the clearest results of this study was the high heterogeneity of BIM expertise among professional disciplines, as reflected all observed variables: levels of use, capabilities, benefits, and satisfaction levels. Architects had the highest levels of use, showed the greatest knowledge of the technology, used the most advanced capabilities, perceived the greatest benefits, and were the most satisfied with the technology. On the contrary, MEP engineers had the worst and lowest results in all these variables. Structural engineers and contractors resided somewhere in between. While this pattern was clearly observed in both surveys, the differences and distances between disciplines were more accentuated in the most recent survey.

It is difficult to fully understand the reasons for these differences, but the data suggest that lack of knowledge about the technology can be an influential factor. About $66.1 \%$ of non-users MEP engineers had no knowledge about BIM. Out of the group who were aware of it, about $69 \%$ believed that it was "not useful in MEP works". Needless to say, there is overwhelming evidence in support of the opposite (Yuan \& XueYuan, 2010; Wang, Wang, Shou, Chong \& Guo, 2016; Khanzode, Fischer \& Reed, 2008).

\section{Limited multidisciplinary collaboration}

Although, overall, the use of BIM increases, the study showed that it is nonetheless characterized by fragmented and non-collaborative practices. Professionals work with the technology independently, with no collaboration between disciplines and no integration of information among sources. The majority use BIM software only for stand-alone capabilities, such as visualization during the design process and generation of traditional 2D technical documentation. Very few professionals share their models with other professionals or with clients. In fact, 2D CAD files represent the main platform for communication with peers, even among BIM users. Cloud-based centralized BIM models are practically non-existent.

In addition, there are no public records of projects in Chile developed under Integrated Project Delivery (IPD) schemes, which are strongly associated with collaborative uses of BIM technology.

The fragmentation of BIM practices is directly related to the heterogeneity among disciplines. As it is seemingly impossible to assemble project teams where all members share a similar level of training in the technology, some of the most valuable BIM capabilities based on collaborative work remain out of reach. Advanced users are forced to keep BIM in-house and continue utilizing CAD formats or traditional paper documentation for all external communication and collaboration. 
The heterogeneity and fragmentation of BIM practices in the industry is extremely detrimental to the effectiveness of the technology. The most fundamental principles of BIM reside in the integration of information and collaborative work. Without these, the technology is reduced to merely being a convenient and improved 3D modeling tool.

\section{Consulting companies assuming leadership}

The market response to the heterogeneity and fragmentation of the BIM industry has been the emergence of BIM consulting firms offering outsourced BIM modeling and coordination services. In general, these companies build BIM models from the 2D CAD information delivered by designers and other consultants and produce design review reports that are used to facilitate project coordination tasks and to supplement construction documents. They do not deliver BIM models, only reports.

Although the market share of BIM consulting companies is low ( $3 \%$ in the period), its impact cannot be underestimated.

On the one hand, these consulting companies have been effective in extending the benefits of using BIM among those who are not direct users of the technology. For example, MEP systems coordination is usually carried out using BIM consulting companies. On the other hand, the companies have contributed to spreading the misconception that BIM is an additional service for a traditional project that is outsourced a posteriori. In fact, $20 \%$ of non-users believe that the main function of the technology is to help coordinating structural and MEP systems.

While the study shows that the services offered by these companies effectively contribute to reducing errors and omissions in construction documents, the results also suggest that the benefits achieved are substantially lower than those achievable with a more direct and potentially integrated use of the technology. Both the level of satisfaction and the level of perceived economic benefits by direct users (regular and occasional) were statistically significantly higher than those of indirect users.

\section{Lack of standardization}

There are no BIM standards in Chile. Compared to other countries, the Chilean AECO industry is significantly behind in this area. In fact, this study reveals that there are no signals of the creation of a widespread national or professional standard, at least in the short term.

As each AECO firm works with BIM independently, each has its own practices and internal pseudo-standards. BIM models are normally not shared, and therefore interoperability issues are not important. Less than $1 \%$ of respondents had tested or used Industry-Foundation Classes (IFC) or other open standards in their projects. They are not required even in public projects.

Yet this situation is not surprising. As a background, the Chilean AECO industry is characterized by the lack of a culture of standardization. Not only are there no BIM standards, there are no CAD standards. Officially, some drawings standards exist for traditional paper-based documentation, but in practice these are neither used nor enforced.

Even so, it is surprising that $71.1 \%$ of respondents declared that it is necessary to create a nation-wide BIM standard. One possible explanation for this percentage is the effect of the communication efforts made by universities and professional organizations which have insisted that BIM standardization is needed. This percentage is significantly higher (98.2\%) among academics.

\section{Uncertain role of the government}

In many countries the influence of the government on the diffusion of BIM has been significant (Wong et al., 2009). In Chile, the government has also had a visible interest in the technology since at least 2010 (Lagunas, 2016), but the concrete effects are still uncertain.

The use of BIM in the public sector has been concentrated exclusively in complex buildings, such as hospitals, airports, and large schools. Although these projects attract considerable attention by the media, they represent only a minor part of the total public construction. Most public projects, excluding civil works, comprise housing projects for lowincome populations. 
Of the total number of BIM users, the vast majority indicated that the main motivation for the implementation of the technology was their "own initiative" (65.4\%). Only $24.0 \%$ indicated that it was required by a public entity or for a public project.

However, it is still too early to reject or even weigh the influence of the public sector in the diffusion of BIM in Chile. In 2016, the Government of Chile formalized a plan that would require the use of BIM in all public projects by the year 2020 (Plan BIM, 2017). The effects of this plan have yet to be evaluated.

\section{Conclusions}

This paper analyzed the evolution of the macro-scale adoption of BIM in Chile during the 2003-2016 period based on two national surveys of AECO professionals.

This study described industry with a positive rate of BIM adoption that has already surpassed critical mass. Almost all metrics in the study seem to confirm that this trend will continue to grow over the next few years.

However, the study also showed that the use of BIM, while increasing, is far from ideal. Dramatic differences in BIM expertise were observed among AECO disciplines, which in turn leads to heterogeneous, fragmented, and noncollaborative BIM practices. BIM technology is being used mostly for basic functions without taking advantage of the synergies that arise when multidisciplinary work is integrated into a single model. In addition, there are no national BIM standards, nor are substantive efforts to create such standards in the short term.

The market response to this problem has been the emergence of consulting companies that offer outsourced BIM modeling services, thus acting as intermediaries among professionals who continue to work independently in traditional CAD-based or paper-based schemes. Although these companies effectively contribute to reducing errors in projects, they have also contributed to spreading the misconception that BIM is an additional service that can be outsourced a posteriori.

This outlook might change in coming years. Professional associations have started several diffusion programs to promote a more integrated use of the technology, while the Chilean government has announced a plan to require the use of BIM in all public projects by 2020 . The main challenges to be addressed by these private and public efforts are related to increasing standardization, reducing technology gaps between disciplines, and promoting collaboration. Developing an industry-wide BIM standard seems to be the key piece for increasing adoption and maturity in the country.

\section{Acknowledgments}

We sincerely thank all professional institutions that collaborated with this research: Colegio de Arquitectos de Chile, Colegio de Ingenieros de Chile, Colegio de Constructores e Ingenieros Constructores de Chile, Asociación de Oficinas de Arquitectos, Asociación de Ingenieros Civiles Estructurales, Cámara Chilena de la Construcción, Corporación de Desarrollo Tecnológico de Chile, and BIM Forum Chile.

References

AGC-Associated General Contractors of America (2007). The Contractors' Guide to BIM. Arlington, VA: Associated General Contractors of America.

Anker Jensen, P., \& Ingi Jóhannesson, E. (2013). Building information modelling in Denmark and Iceland. Engineering, Construction and Architectural Management, 20(1), 99-110.

ASOBIM-Asociación Colombiana de BIM (2017). Asociación Colombiana de BIM: ¿Qué es ASOBIM? Retrieved from http://asociacioncolombianabim.co/asobim-3/

Azhar, S. (2011). Building information modeling (BIM): Trends, benefits, risks, and challenges for the AEC industry. Leadership and management in engineering, 11(3), 241-252.

Barlish, K., \& Sullivan, K. (2012). How to measure the benefits of BIM-A case study approach. Automation in Construction, 24, 149-159.

BCA-Building and Construction Authority (2012). Singapore BIM Roadmap. Singapore: Singapore Building and Construction Authority.

BFA-BIM Forum Argentina (2017). BIM Forum Argentina: Quienes Somos. Retrieved from http://bimforum.org.ar/quienes-somos

BFCh-BIM Forum Chile (2017). ¿Qué es BIM Forum Chile? Retrieved from http://www.bimforum.cl/que-es-bim-forum-chile/ 
BFM-BIM Forum México (2017). BIM Forum México: Quienes Somos. Retrieved from at http://bimforummexico.mx/quienes-somos/

BIM Latam (2015). I Congreso Latinoamericano BIM LATAM. Programa 2015. Retrieved from http://www.bimlatam.la

BIM Latam (2016). I/ Congreso Latinoamericano BIM LATAM. Programa 2016. Retrieved from: http://www.bimlatam.la

Bonilla, A. \& Garcia, R. (2017) Integración BIM de sistemas solares térmicos en diseño inicial de viviendas. Revista de la Construcción, 16(2), 323-338. ISSN 0718-915X. http://dx.doi.org/10.7764/rdlc.16.2.323.

Botero, L., Isaza, J., \& Vásquez, A. (2015). Estado de la práctica del BIM-Colombia 2015. Paper presented at SIBRAGEC ELAGEC 2015 Conference, San Carlos, Brasil, 7-9 Oct.

Bryde, D., Broquetas, M., \& Volm, J. M. (2013). The project benefits of building information modelling (BIM). International Journal of Project Management, 31(7), 971-980.

Bui, N., Merschbrock, C., \& Munkvold, B. E. (2016). A review of Building Information Modelling for construction in developing countries. Procedia Engineering, 164, 487-494.

buildingSMART (2017). The BIM Guides Project. Retrieved from http://bimguides.org/bin/view/Main/

Cao, D., Wang, G., Li, H., Skitmore, M., Huang, T., \& Zhang, W. (2015). Practices and effectiveness of building information modelling in construction projects in China. Automation in Construction, 49, 113-122.

Carvalho, P. M. P. (2016). Análise Estatística do Estado de Implementação da Tecnologia Bim no Setor da Construção em Portugal. Dissertação submetida para satisfação parcial dos requisitos do grau de Mestre Em Engenharia Civil, Universidade do Porto, Porto, Portugal.

Chapple, P. (2009). Aplicación de BIM: Herramienta Modelo. Revista BIT, Corporación de Desarrollo Tecnológico, September, 56-58.

Checcucci, E. S., Pereira, A. P. C., \& Amorim, A. L. D. (2011). A difusão das tecnologias BIM por pesquisadores do Brasil. Paper presented at Encontro Tecnologia De Informação E Comunicação Na Construção, Salvador de Bahia, Brasil, August 5-7.

Chiappa, F. (2010). BIM: Mas que 3D. Revista BIT Corporación de Desarrollo Tecnológico, November, 72-75.

CRC- Cooperative Research Centre for Construction Innoovation (2009) National Guidelines for Digital Modelling. Brisbane: Cooperative Research Centre for Construction Innoovation.

CDT-Corporación de Desarrollo Tecnológico (2010). Implementación y Promoción de la Tecnología BIM en Chile. Proyecto Difusión y Transferencia Tecnológica 2010-7690-INNOVA

de Andrade, M. L. V. X., \& Ruschel, R. C. (2009). BIM: conceitos, cenário das pesquisas publicadas no Brasil e tendências.Simpósio Brasileiro de Qualidade do Projeto no Ambi ente Construído. IX Workshop Brasileiro de Gestão do Processo de Projeto na Construção de Edifícios, Universidade de São Paulo.

Ding, Z., Zuo, J., Wu, J., \& Wang, J. Y. (2015). Key factors for the BIM adoption by architects: A China study. Engineering, Construction and Architectural Management, 22(6), 732-748.

Eadie, R., Browne, M., Odeyinka, H., McKeown, C., \& McNiff, S. (2015). A survey of current status of and perceived changes required for BIM adoption in the UK. Built Environment Project and Asset Management, 5(1), 4-21.

Eastman, C. (2016). The next step. 2016 National BIM Survey Chile: Views from leading experts. Retrieved from http://www.bim.uchilefau.cl

Eastman, C., Teicholz, P., Sacks, R. \& Liston, K. (2011). BIM Handbook: A Guide to Building Information Modeling for Owners, Managers, Designers, Engineers and Contractors. John Wiley \& Sons.

Enegbuma, W. I., \& Ali, K. N. (2011). A preliminary study on building information modeling (BIM) implementation in Malaysia. In Proceedings of 3rd International Postgraduate Conference on Infrastructure and Environment (IPCIE2011). Hong Kong.

Ferreira, B. (2012). Integração da Tecnoflogia BIM no Projeto de Estruturas de Betão. Paper presented at Encontro Nacional BETÃO ESTRUTURAL, Porto, Portugal, 24-26 October

Froise, T., \& Shakantu, W. (2014). Diffusion of innovations: an assessment of building information modelling uptake trends in South Africa. Journal of Construction Project Management and Innovation, 4(2), 895-911.

FIC-Fundación de la Industria de la Construcción (2017). Encuesta BIM 2017. Retrieved from http://bimforummexico.mx/

GSA-General Services Administration (2009). GSA Building Information Modeling Guide Series. Washington: US General Services Administration, Public Building Service.

Gu, N., Singh, V., \& London, K. (2014). BIM ecosystem: the coevolution of products, processes, and people. Building information modeling: BIM in current and future practice, 197-210.

Gu, N., Singh, V., Taylor, C., London, K., \& Brankovic, L. (2010). BIM adoption: expectations across disciplines. In Handbook of research on building information modeling and construction informatics: concepts and technologies (pp. 501-520). IGI Global.

Henttinen, T. (2010). BIM in Finland. Paper presented at Bips Conference buildingSMART, Nyborg, Denmark 6-10 September

Hooper, M. (2015). BIM standardisation efforts-the case of Sweden. Journal of Information Technology in Construction (ITcon), 20(21), 332-346 
Jung, W., \& Lee, G. (2015). The status of BIM adoption on six continents. International Journal of Civil, Environmental, Structural, Construction and Architectural Engineering, 9(5), 444-448.

Kassem, M., Leusin de Amorim, S. R. (2015) BIM Building Information Modeling No Brasil e na União Europeia. Middlesbrough, England: Teesside University, Technology Futures Institute

Kassem, M., Succar, B., \& Dawood, N. (2013). A proposed approach to comparing the BIM maturity of countries. Paper presented at CIB W78 2013 30th International Conference on the Applications of IT in the AEC Industry, Beijing, China, 9-12 October

Kekana, T. G., Aigbavboa, C. O., \& Thwala, W. D. (2014). Building Information Modelling (BIM): Barriers in Adoption and Implementation Strategies in the South Africa Construction Industry. Paper presented at the International Conference on Emerging Trends in Computer and Image Processing (ICETCIP'2014) December.

Khanzode, A., Fischer, M., \& Reed, D. (2008). Benefits and lessons learned of implementing building virtual design and construction (VDC) technologies for coordination of mechanical, electrical, and plumbing (MEP) systems on a large healthcare project. Journal of Information Technology in Construction (ITcon), 13(22), 324-342.

Khosrowshahi, F., \& Arayici, Y. (2012). Roadmap for implementation of BIM in the UK construction industry. Engineering, Construction and Architectural Management, 19(6), 610-635.

Kjartansdóttir, I. B. (2012). BIM adoption in Iceland and its relation to lean construction. Master of Science in Construction Management, Reykjavík University, Reykjavík.

Kumar, J. V., \& Mukherjee, M. (2009). Scope of building information modeling (BIM) in India. Journal of Engineering Science and Technology Review, 2(1), 165-169.

Lagunas. H. (2016). Estándares y Procesos para la implementación de BIM en Proyectos Públicos. Retrieved from http://www.planbim.cl/Programa_seminario.html3

Latiffi, A. A., Mohd, S., Kasim, N., \& Fathi, M. S. (2013). Building information modeling (BIM) application in Malaysian construction industry. International Journal of Construction Engineering and Management, 2(A), 1-6.

Leon, J.C. (2017). INCONET: Firme Posicionamiento de BIM en Latinoamérica. Encuesta BIM Latinoamericana. Federación Interamericana de la Industria de la Construcción, FIIC. Retrieved from http://fiic.la/blog/2017/07/03/inconet-firme-posicionamiento-de-bim-en-latinoamerica/

Lobos, D. (2016a) A timeline for BIM in Chile. Presented at the 4th Jornada BIM Chile, Universidad de las Américas, 1st September 2016, Santiago de Chile

Lobos, D. (2016b). Estado del BIM en Universidades. Retrieved from http://community.bimtool.com/2016/12/12/estado-del-bim-en-universidades/

Lobos, D. (2013). Términos de Referencia Uso de modelos BIM. Dirección de Arquitectura MOP. Implementación de Tecnologías BIM (Building Information Modeling) en el proceso de toma de decisiones de las licitaciones del MOP VIII región.

Loyola, M. (2013). Encuesta Nacional BIM 2013: Informe de Resultados. Departamento de Arquitectura, Universidad de Chile. Retrieved from http://www.bim.uchilefau.cl

Loyola, M. (2016a). Encuesta Nacional BIM 2016: Informe de Resultados. Departamento de Arquitectura, Universidad de Chile. Retrieved from http://www.bim.uchilefau.cl

Loyola, M. (2016b). 2013 National BIM Survey: Summary of Results. Departamento de Arquitectura. Universidad de Chile.

Luthra, A. (2010). Implementation of building information modeling in architectural firms in India. Master of Science, Purdue University.

McGraw-Hill Construction (2014a). The business value of BIM in Australia and New Zealand: How building information modelling is transforming the design and construction industry. SmartMarket Report. Bedford, Massachusetts: McGraw Hill Construction.

McGraw-Hill Construction. (2009). The business value of BIM. Smart Market Report. Bedford, Massachusetts: McGraw Hill Construction

McGraw-Hill Construction. (2010). The business value of BIM in Europe: Getting Building Information Modelling To The Bottom Line The United Kingdom, France And Germany. Smart Market Report. Bedford, Massachusetts: McGraw Hill Construction

McGraw-Hill Construction. (2012a). The business value of BIM in North America: multi-year trend analysis and user ratings (2007-2012). Smart Market Report. Bedford, Massachusetts: McGraw Hill Construction

McGraw-Hill Construction. (2012b). The Business Value of BIM in South Korea. SmartMarket Report. Bedford, Massachusetts: McGraw Hill Construction

McGraw-Hill Construction. (2014b). The Business Value of BIM in Major Global Markets. SmartMarket Report. Bedford, Massachusetts: McGraw Hill Construction

Mohd-Nor, M. F. I., \& Grant, M. P. (2014). Building information modelling (BIM) in the malaysian architecture industry. Transactions on Environment and Development, 10, 264-273.

Montoya, K. (2008). Bim Software: aproximación a las implicancias económico-sociales de su potencial implementación. Seminario (arquitecto)-Universidad de Chile, Facultad de Arquitectura y Urbanismo.

Movsisyan, N. (2016). BIM technology in Denmark. BA Dissertation, Copenhagen School of Design and Technology.

Nala, T. (2016) Avances BIM en el Ministerio de Obras Públicas. Retrieved from http://www.planbim.cl/Programa_seminario.html3 
NBS (2017). NBS National BIM Report 2013. NBS, UK, 2017 Retrieved from https://www.thenbs.com/knowledge/nbs-international-bim-report-2013 OGUC (2016). Ordenanza General de Urbanismo y Construcciones. Ministerio de Vivienda y Urbanismo de Chile. D.S. 47 of 1992.

Pavez, A. (2012). Desarrollos BIM tocando la Nube. Revista BIT Corporación de Desarrollo Tecnológico, Julio, 76-80.

Plan BIM (2017). ¿Qué es Planbim?. Retrieved from http://www.planbim.cl

RTS (2013). Finnish BIM survey 2013. The Building Information Foundation RTS. Retrieved from https://www.rakennustieto.fi/material/attachments/ tutkimus-_ja_kehittamistoimita/6JKcTDSMO/BIM_Survey_Finland_findings.pdf

Ruiz, D. (2012) BIM Modelando Innovación. Revista BIT Corporación de Desarrollo Tecnológico, Marzo, 32-35.

Saavedra, A. (2016). Avances de BIM en Chile Crecimiento en la Industria. Revista BIT Corporación de Desarrollo Tecnológico, Septiembre, 20-27

Sattineni, A., \& Bradford, R. H. (2011). Estimating with BIM: A survey of US construction companies. Proceedings of the 28th ISARC, Seoul, Korea, 564569.

Sawhney, A., Kapoor, A., Kamthan, S., Agarwal, N., Bhakre, P., \& Jain, S. (2014). State of BIM adoption and outlook in India. RICS Research, Dillí. Retrieved from http://www.fig.net/resources/proceedings/fig_proceedings/fig2014/ppt/ss36/ss36_kavanagh_7434.pdf

Serpell, A., de Solminihac, H., \& Figari, C. (2002). Quality in construction: The situation of the Chilean construction industry. Total quality management, $13(5), 579-587$.

Sharif, T. (2011). BIM in the Middle East. Middle-East buildingSMART, 64.

Silva, M. J. F., Salvado, F., Couto, P., \& e Azevedo, Á. V. (2016). Roadmap Proposal for Implementing Building Information Modelling (BIM) in Portugal. Open Journal of Civil Engineering, 6(03), 475.

Silvia, A., del Solar, P., de la Peña, A., \& Vivas, M. D. (2017). Implementation of BIM in Spanish construction industry. Building \& Management, 1(1), 1.

Smith, P. (2014). BIM implementation-global strategies. Procedia Engineering, 85, 482-492.

Soto. C. (2016). Estrategia del Plan BIM de Chile - Colaboración UK [video]. Retrieved from http://www.planbim.cl/Programa_seminario.html

Statsbygg (2017). Statsbygg Building Information Modelling Manual Version 1.2.1 (SBM1.2.1). Retrieved from http://www.statsbygg.no/files/publikasjoner /manualer/StatsbyggBIM-manual-ver1-2-1eng-2013-12-17.pdf

Teo, X. Q. (2012). A study of building information modeling (BIM) in Malaysia construction industry, Doctoral dissertation, UTAR.

Wang, J., Wang, X., Shou, W., Chong, H. Y., \& Guo, J. (2016). Building information modeling-based integration of MEP layout designs and constructability. Automation in Construction, 61, 134-146.

Won, J., Lee, G., and Park, Y. (2010). 2010 Survey on BIM Adoption in Korea. buildingSMART Korea. Retrieved from http://www.buildingsmart.or.kr/

Wong, A. K. D., Wong, F. K., \& Nadeem, A. (2009). Comparative roles of major stakeholders for the implementation of BIM in various countries. In Proceedings of the International Conference on Changing Roles: New Roles, New Challenges, Noordwijk Aan Zee, The Netherlands (pp. 5-9).

Wong, A. K., Wong, F. K., \& Nadeem, A. (2010). Attributes of building information modelling implementations in various countries. Architectural Engineering and Design Management, 6(4), 288-302.

$\mathrm{Xu}$, H., Feng, J., \& Li, S. (2014). Users-orientated evaluation of building information model in the Chinese construction industry. Automation in Construction, 39, 32-46.

Yuan, G., \& XueYuan, D. (2010). A study of BIM-based MEP technologies in building design. Journal of Information Technology in Civil Engineering and Architecture, 2, 019.

Zhang, L., Wang, G., Chen, T., \& He, G. (2014). Survey of BIM application status and characteristics in China. Proceedings of the 17th International Symposium on Advancement of Construction Management and Real Estate, Berlin, Heidelberg, 969-979. 